\title{
Biomarkers in Medicine: Foreword
}

\author{
Adam Tarring ${ }^{*}, 1$ \\ ${ }^{1}$ Future Science Group, Unitec House, 2 Albert Place, London N31QB, UK \\ * Author for correspondence: a.tarring@futuremedicine.com
}

Welcome to Volume 12 of Biomarkers in Medicine (BMM). In this foreword, we will present some of the highlights of the last 12 months as well as discussing what we are looking forward to in the year ahead.

We would also like to take this opportunity to thank our readers, reviewers, authors and Editorial Board members for their support in the last year and look forward to working with everyone as we move into the New Year.

\section{Content highlights of 2017}

2017 was another great year for the journal, with the high number of submissions and articles looking better than ever on our new website [1]. The top ten most read articles of the past year are shown in Table 1; these articles show the diverse research that is being done in the field as well as some of the key focus areas. The key focus areas included biomarkers for cancer and for neurodegenerative disease; we would expect these areas to continue to be areas of focus in the coming year.

\section{Readership demographics}

The readership of the journal is shown in Figure 1, with the majority of readers coming from Asia (41\%), North America (29\%) and Europe (27\%). While our content is reaching established scientific communities, we hope to see growth in emerging scientific communities in South America and Africa, to have our content reach a truly global audience.

\section{Social media}

BMM is active across social media, including LinkedIn [12] and at @fsgbmm on Twitter [13]. We regularly post on the latest news in field and provide updates on what is being published in the journal. We have enjoyed the interactions that we have had with everyone on these platforms and look forward to continuing these in the future.

\section{Conclusion}

We appreciate any feedback on the direction of the journal, especially any priority topics that deserve recognition in the journal. We welcome unsolicited research, review and opinion article proposals, and would be delighted to hear from you if you are interested in submitting to the journal. For submitting authors, BMM offers various services to increase the speed and reach of their articles - including our accelerated publication and open access options. Interested readers can find out more on our website [14].

Many thanks for your continuing interest and support of BMM, we look forward to working with many of you over the coming year. 


\begin{tabular}{|c|c|c|c|c|}
\hline Rank & Title & Study & $\begin{array}{l}\text { Volume } \\
\text { (issue) }\end{array}$ & Ref. \\
\hline 1 & Can nanotechnology improve cancer diagnosis through miRNA detection? & Fiammengo $\mathrm{R}$ & $11(1)$ & [2] \\
\hline 2 & $\begin{array}{l}\text { The Systemic Synuclein Sampling Study: toward a biomarker for Parkinson's } \\
\text { disease }\end{array}$ & Visanji NP, Mollenhauer B, Beach TG et al. & $11(4)$ & [3] \\
\hline 3 & $\begin{array}{l}\text { Correlations between IncRNA-SOX2OT polymorphism and susceptibility to } \\
\text { breast cancer in a Chinese population }\end{array}$ & Tang X, Gao Y, Yu L et al. & $11(3)$ & [4] \\
\hline 4 & $\begin{array}{l}\text { miRNA profiling for the early detection and clinical monitoring of diabetic } \\
\text { kidney disease }\end{array}$ & DiStefano JK & $11(2)$ & [5] \\
\hline 5 & $\begin{array}{l}\text { Reproducibility in biomarker research and clinical development: a global } \\
\text { challenge }\end{array}$ & Scherer A & $11(4)$ & [6] \\
\hline 6 & Nanocytology as a potential biomarker for cancer & Yu W, Sharma S, Gimzewski JK, Rao J & $11(3)$ & [7] \\
\hline 7 & Fetal cells in maternal blood for prenatal diagnosis: a love story rekindled & Singh R, Hatt L, Ravn K et al. & 11(9) & [8] \\
\hline 8 & $\begin{array}{l}\text { RAS mutation prevalence among patients with metastatic colorectal } \\
\text { cancer: a meta-analysis of real-world data }\end{array}$ & Kafatos G, Niepel D, Lowe K et al. & 11(9) & [9] \\
\hline 9 & $\begin{array}{l}\text { Actinin- } 4 \text { protein overexpression as a predictive biomarker in adjuvant } \\
\text { chemotherapy for resected lung adenocarcinoma }\end{array}$ & Shiraishi H, Fujiwara Y, Kakuya T et al. & 11(9) & [10] \\
\hline 10 & $\begin{array}{l}\text { Genomic heterogeneity: next-generation sequencing enables biomarker } \\
\text { identification for hepatocellular carcinoma }\end{array}$ & $\begin{array}{l}\text { Ziogas DE, Lykoudis EG, Roukos DH, Glantzounis } \\
\text { GK }\end{array}$ & $11(7)$ & [11] \\
\hline
\end{tabular}

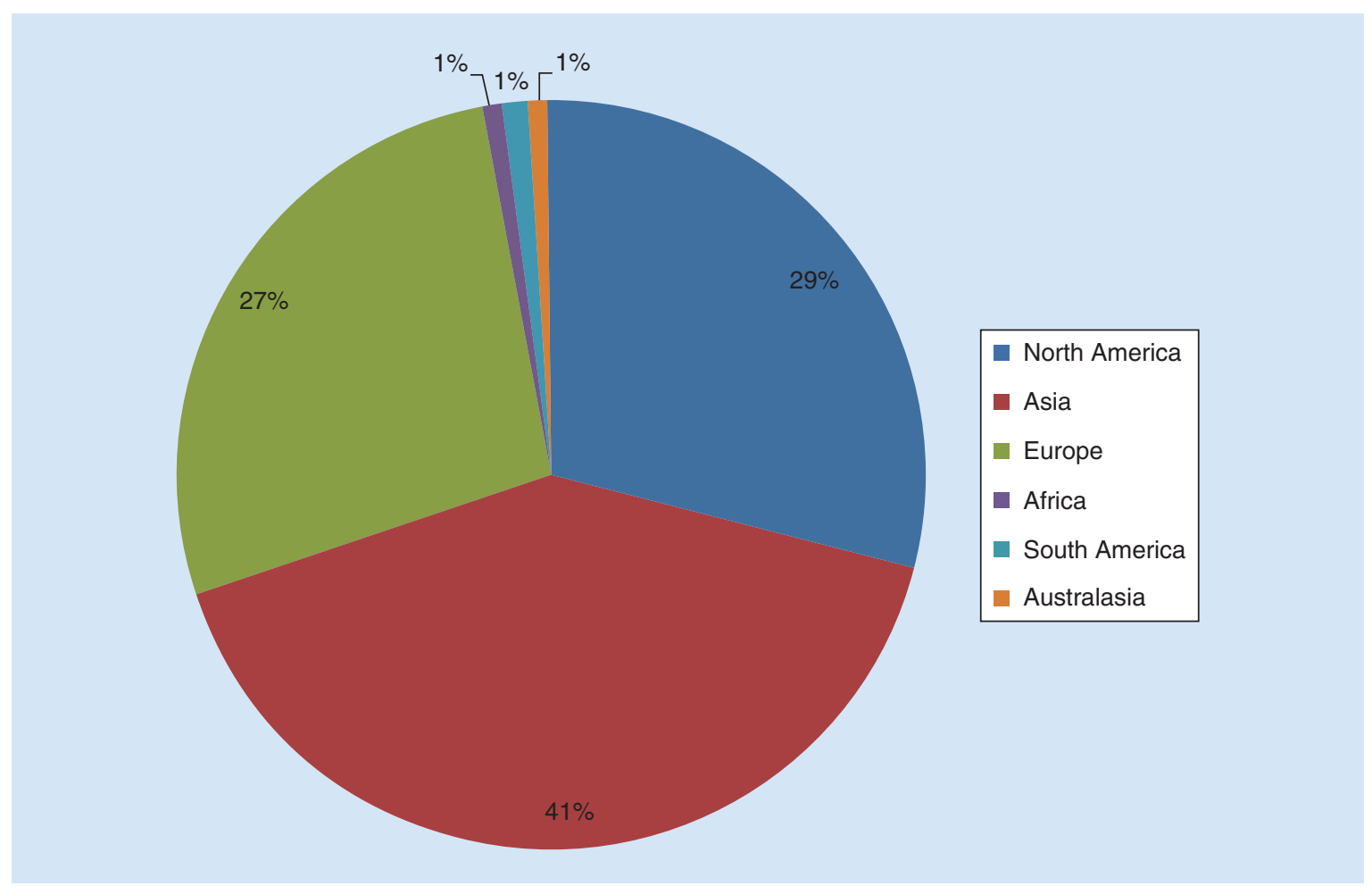

Figure 1. Biomarkers in Medicine reader demographics 2017. 


\section{Financial \& competing interests disclosure}

A Tarring is an employee of Future Science Ltd, publisher of Biomarkers in Medicine. The author has no other relevant affiliations or financial involvement with any organization or entity with a financial interest in or financial conflict with the subject matter or materials discussed in the manuscript apart from those disclosed.

No writing assistance was utilized in the production of this manuscript.

\section{References}

1 Biomarkers in Medicine website. www.futuremedicine.com/journal/bmm?journalCode=bmm

2 Fiammengo R. Can nanotechnology improve cancer diagnosis through miRNA detection? Biomark. Med. 11(1), 69-86 (2017).

3 Visanji NP, Mollenhauer B, Beach TG et al. The Systemic Synuclein Sampling Study: toward a biomarker for Parkinson's disease. Biomark. Med. 11(4), 359-368 (2017).

4 Tang X, Gao Y, Yu L et al. Correlations between lncRNA-SOX2OT polymorphism and susceptibility to breast cancer in a Chinese population. Biomark. Med. 11(3), 277-284 (2017).

5 DiStefano JK. miRNA profiling for the early detection and clinical monitoring of diabetic kidney disease. Biomark. Med. 11(2), 99-102 (2017).

6 Scherer A. Reproducibility in biomarker research and clinical development: a global challenge. Biomark. Med. 11(4), 309-312 (2017).

7 Yu W, Sharma S, Gimzewski JK, Rao J. Nanocytology as a potential biomarker for cancer. Biomark. Med. 11(3), 213-216 (2017).

8 Singh R, Hatt L, Ravn K et al. Fetal cells in maternal blood for prenatal diagnosis: a love story rekindled. Biomark. Med. 11(9), 705-710 (2017).

9 Kafatos G, Niepel D, Lowe K et al. RAS mutation prevalence among patients with metastatic colorectal cancer: a meta-analysis of real-world data. Biomark. Med. 11(9), 751-760 (2017).

10 Shiraishi H, Fujiwara Y, Kakuya T et al. Actinin-4 protein overexpression as a predictive biomarker in adjuvant chemotherapy for resected lung adenocarcinoma. Biomark. Med. 11(9), 721-731 (2017).

11 Ziogas DE, Lykoudis EG, Roukos DH, Glantzounis GK. Genomic heterogeneity: next-generation sequencing enables biomarker identification for hepatocellular carcinoma. Biomark. Med. 11(7), 515-518 (2017).

12 Linkedin Group: Biomarkers in Medicine. www.linkedin.com/groups/8444085

13 Twitter: Biomarkers in medicine. https://twitter.com/fsgbmm

14 Future Science Group Publishing Solutions. www.future-science-group.com/services/for-professionals/publication-solutions/ 
